\title{
KAJIAN STRUKTUR BANGUNAN AKIBAT PENURUNAN MUTU BETON PADA KOLOM TERPASANG \\ (Studi Kasus: SDN 01 Cikaret Kabupaten Bogor)
}

\author{
Muhamad Lutfi, Subtoni \\ Program Studi Teknik Sipil, Universitas Ibn Khaldun Bogor \\ E-mail: opomsubtoni@yahoo.com
}

\begin{abstract}
ABSTRAK
Bangunan sekolah selayaknya harus memenuhi persyaratan teknis yang telah ditetapkan dan diatur didalam Undang- undang Bangunan Gedung No. 28 Tahun 2002 bahwa setiap gedung harus memiliki asas kemanfaatan, keselamatan, kenyamanan dan keserasian dengan lingkungannya. SDN 01 Cikaret tengah melakukan rehabilitasi bangunan namun pada pelaksanaannya ditemukan kondisi dimana beton mengalami perubahan fisik yaitu berupa pelapukan hal itu diduga terjadi akibat penurunan mutu beton pada kolom tersebut, dengan demikian akan menyebabkan kolom menjadi rusak dan daya dukung kolom serta kekuatan struktur bangunan sekolah akan berkurang. Pengujian mutu beton akan dilakukan dengan cara uji tanpa merusak dengan hammer test sehingga akan didapat nilai mutu beton yang terdapat pada bangunan, nilai dari hammer test itu kemudian dianalisis dengan menggunakan softwere Etabs dengan memperhitungkan berat beban yang harus diterima oleh bangunan baik itu beban hidup, beban mati, dan beban gempa, yang kemudian dikombinasikan dan dianalisis kembali secara manual sehingga diperoleh hasil dimana warna merah yang muncul pada permodelan di semua struktur bangunan kemudian dengan hitungan manual didapatkan hasil dengan diagram interaksi kolom dimana nilai $\mathrm{R}$ (pertemuan garis $\mathrm{Pu}$ dan $\mathrm{Mu}$ ) berada diluar diagram interaksi kuat rencana, setelah itu dilakukan perencanaan ulang dengan menggunakan mutu beton K-225 diperoleh hasil dimana dengan permodelan softwere Etabs ditunjukkan dengan warna ungu yang berarti struktur aman dan hitungan manual dengan diagram interaksi kolom hasil dimana nilai $\mathrm{R}$ (pertemuan garis $\mathrm{Pu}$ dan $\mathrm{Mu}$ ) berada didalam diagram interaksi kuat rencana. Sehingga dapat disimpulkan bahwa kolom pada bangunan eksisting sudah tidak dapat menahan beban bangunan diatasnya sedangkan dengan perencanaan mutu beton K-225 struktur kolom mampu menahan beban struktur atasnya.
\end{abstract}

Kata Kunci: Hammer test; Sotwere Etabs; Struktur Kolom.

\section{ABSTRACT}

School buildings should meet the technical requirements that have been determined and regulated in Building Law No. 28 of 2002 that every building must have the principles of expediency, safety, comfort and harmony with its environment. SDN 01 Cikaret is undergoing rehabilitation of the building but in its implementation it was found that the concrete experienced physical changes in the form of weathering was thought to occur due to a decrease in the quality of concrete in the column, thereby causing the column to become damaged and the carrying capacity of the column and the strength of the school building structure to be reduced. Concrete quality testing will be carried out by means of a test without damaging the hammer test so that the concrete quality values contained in the building will be obtained, the value of the hammer test is then analyzed using Softwares Etabs by calculating the weight of the load that must be received by the building both the living load, the burden dead, and earthquake load, which is then combined and analyzed manually again so that the results obtained where the red color that appears in the modeling in all building structures and then with a manual count results obtained with a column interaction diagram where the value of $R$ (meeting $\mathrm{Pu}$ and $\mathrm{Mu}$ lines) is outside strong interaction diagram of the plan, after that re-planning using $K-225$ concrete quality results obtained where the modeling of Etabs softwere shown in purple which means the structure is safe and manual count with the results column interaction diagram where the value of $R$ (meeting lines $\mathrm{Pu}$ an) are in the diagram of the strong interaction plan. So it can be concluded that the columns in the existing building can no longer bear the weight of the building above, whereas with the K-225 concrete quality planning the column structure is able to withstand the high structural load.

Keywords: Hammer test; Sotwere Etabs; Column Structure.

\section{PENDAHULUAN}

Berdasarkan Keputusan Menteri

Pekerjaan Umum No. 441 tahun 1998 tentang

persyaratan teknis bangunan gedung, maka bangunan sekolah termasuk kelas yaitu 
Muhamad Lutfi, Subtoni, Kajian Struktur Bangunan Akibat Penurunan Mutu Beton Pada Kolom Terpasang (Studi Kasus: Sdn 01 Cikaret Kabupaten Bogor)

bangunan gedung yang dipergunakan untuk melayani kebutuhan masyarakat umum. Bangunan sekolah selayaknya harus memenuhi persyaratan teknis yang telah ditetapkan dan diatur didalam Undang- undang Bangunan Gedung No. 28 Tahun 2002 tentang bangunan gedung, bahwa setiap gedung harus memiliki asas kemanfaatan, keselamatan, kenyamanan dan keserasian dengan lingkungannya. Aspek keselamatan suatu bangunan sekolah tidak terlepas dari faktor kekuatan elemen struktur atas bangunan sekolah, yang secara umum terdiri elemen balok, kolom dan pelat. Ketiga elemen tersebut sebaiknya pada proses pembuatannya dari tahap awal sampai dengan akhir haruslah dilakukan pemeriksaan yang terencana dan terukur, baik itu menyangkut material yang digunakan, tata laksana, peralatan pendukung dan hasil akhir mutu beton yang digunakan.

Bangunan SDN Cikaret 01 Kecamatan Cibinong telah melakukan rehabilitasi bangunan. Bagian bangunan sekolah yang mengalami rehabilitasi adalah 3 (tiga) ruang kelas pada sisi selatan bangunan. Rencananya pada bagian bangunan sekolah ini akan mengalami peningkatan satu lantai, dimana lantai dasar tetap merupakan ruang kelas dan lantai satu yang sedang dibangun tetap digunakan sebagai ruang kelas tambahan Pada pelaksanaan konstruksi ditemukan suatu kondisi dimana beton pada kolom-kolom bangunan yang menopang lantai 1 mengalami perubahan fisik beton Memperhatikan kondisi fisik bangunan SDN Cikaret 01 kecamatan Cibinong Kabupaten Bogor, dianggap perlu dilakukan suatu kajian analisis struktur akibat penurunan mutu beton tersebut. Hal ini dilakukan untuk melihat apakah bangunan SDN Cikaret 01 Kecamatan Cibinong kabupaten Bogor akan layak digunakan untuk kepentingan belajar mengajar.

\author{
Rumusan Masalah \\ Berdasarkan latar belakang masalah yang \\ telah dipaparkan di atas dapat \\ dirumuskan \\ beberapa permasalahan: \\ 1. Apakah struktur kolom \\ bangunan SDN Cikaret 01 Kecamatan \\ Cibinong Kabupaten Bogor masih dapat \\ menahan struktur diatasnya? dan \\ 2. Bagaimana bentuk pemodelan \\ yang seharusnya supaya kolom tersebut \\ tidak mengalami perubahan fisik?
}

\section{Tujuan Penelitian}

Berdasarkan rumusan masalah di atas, maka tujuan yang akan dicapai dari penelitian ini adalah memperoleh nilai pembebanan dari bangunan SDN Cikaret 01 Kecamatan Cibinong Kabupaten Bogor dan memperoleh bentuk pemodelan eksisting dan pemodelan rencana bangunan tersebut dengan softwere Etabs dan analisis manual.

\section{Nilai Uji Kuat Tekan Beton Struktur Bangunan \\ Kondisi eksisting}

Pelaksanaan konstruksi pada SDN Cikaret 01 kecamatan Cibinong Kabupaten Bogor ditemukan suatu kondisi dimana beton pada kolom-kolom bangunan yang menopang lantai 1 mengalami perubahan fisik beton. Perubahan fisik yang dimaksud adalah beton mengalami gejala pelapukan. Perubahan kondisi fisik kolom yang mengalami gejala pelapukan, diduga terjadi penurunan mutu beton pada kolom terpasang, serta ditakutkan akan menyebabkan kolom menjadi rusak dan sudah barang tentu akan mengakibatkan berkurangnya daya dukung kolom dan kekuatan struktur bangunan sekolah. Kondisi pelapukan yang terjadi ditunjukkan pada Gambar 1.

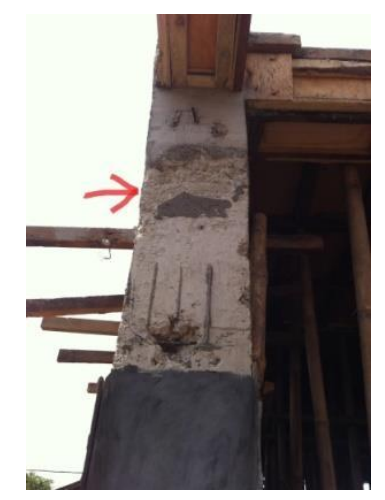

Gambar 1 Kondisi pelapukan yang terjadi

Beban yang bekerja pada kolom bisanya berupa kombinasi antara beban aksial dan 
momen lentur. Besarnya beban aksial dan momen lentur yang mampu ditahan oleh kolom bergantung pada pada ukuran/dimensi kolom, dan jumlah serta letak baja tulangan yang ada/terpasang pada kolom tersebut. Hubungan antara beban aksial dan momen lentur digambarkan dalam suatu diagram yang disebut diagram interaksi kolom $\mathrm{M}-\mathrm{N}$, yaitu dapat memberikan gambaran tentang kekuatan dari kolom yang bersangkutan. Untuk penampang kolom dapat digambarkan diagram kolom yang meliputi 3 macam yaitu diagram interaksi kolom untuk kuat rencana, diagram interaksi untuk kuat nominal dan diagram interaksi untuk kuat batas (kapasitas), tetapi yang ditinjau hanya 2 saja yaitu diagram interaksi untuk kuat rencana dan kuat nominal.

Diagram interaksi kolom dibuat dengan pertolongan 2 buah sumbu (yaitu vertikal dan sumbu horizonta) yang saling berpotongan tegak lurus sesamanya.
Sumbu vertikal menggambarkan besar beban aksial $\mathrm{P}$ atau gaya normal $\mathrm{N}$, sedangkan sumbu horizontal menggambarkan besar momen lentur $M$ yang dapat ditahan oleh kolom. Kolom mampu menahan beban aksial perlu Pudan bebn momen perlu sebesar Mu. Untuk keperluan tersebut, nilai $\mathrm{Pu}$ dan $\mathrm{Mu}$ diplotkan pada sumbu diagram. Kemudian dengan membuat garis horizontal dari beban $\mathrm{Pu}$ dan membuat garis vertikal dari momen Mu, maka diperoleh titik R. Apabila diperoleh titik $\mathrm{R}$ berada di dalam diagram interaksi kuat rencana, maka kolom mampu menahan beban yang bekerja. Tetapi, sebaliknya jika titik $R$ berada diluar diagram interaksi kuat rencana, maka kolom tersebut tidak mampu menahan beban yang bekerja. Contoh diagram interaksi kolom M$\mathrm{N}$ ditunjukkan pada Gambar 2.5.

diagram interaksi kolom $\mathrm{M}-\mathrm{N}$ yang ditunjukkan pada Gambar 2.

(Sumber: Kolom, Pondasi dan Balok T, Ali Asroni)

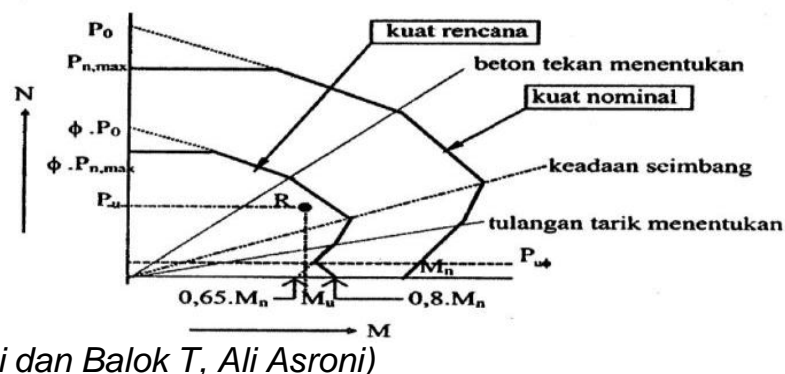

Gambar 2. Diagram interaksi kolom $\mathrm{M}-\mathrm{N}$

\section{Hummer test}

Hammer test yaitu suatu alat pemeriksaan mutu beton tanpa merusak beton. Disamping itu dengan menggunakan metode ini akan diperoleh cukup banyak data dalam waktu yang relatif singkat dengan biaya yang murah. Metode pengujian ini dilakukan dengan memberikan beban intact (tumbukan) pada permukaan beton dengan menggunakan suatu massa yang diaktifkan dengan menggunakan energi yang besarnya tertentu. Jarak pantulan yang timbul dari massa tersebut pada saat terjadi tumbukan dengan permukaan beton benda uji dapat memberikan indikasi kekerasan juga setelah dikalibrasi, dapat memberikan pengujian ini adalah jenis "Hammer". Alat ini sangat berguna untuk mengetahui keseragaman material beton pada struktur. Karena kesederhanaannya, pengujian dengan menggunakan alat ini sangat cepat, sehingga dapat mencakup area pengujian yang luas dalam waktu yang singkat. Alat ini sangat peka terhadap variasi yang ada pada permukaan beton, misalnya keberadaan partikel batu pada bagian-bagian tertentu dekat permukaan. Oleh karena itu, diperlukan pengambilan beberapa kali pengukuran disekitar setiap lokasi pengukuran, yang hasilnya kemudian dirata-ratakan British Standards (BS) mengisyaratkan pengambilan antara 9 sampai 25 kali pengukuran untuk setiap daerah pengujian seluas maksimum 300 mm2. Secara umum alat ini bisa digunakan untuk:

- Memeriksa keseragaman kwalitas beton pada struktur.

- Mendapatkan perkiraan kuat tekan beton.

Kelebihan dari "Hammer test" diantaranya murah, pengukuran bisa dilakukan dengan cepat, praktis (mudah digunakan), tidak merusak sedangkan kekurangan Hammer test yaitu Sulit mengkalibrasi hasil pengujian, tingkat keandalannya rendah, hanya memberikan imformasi mengenai karakteristik beton pada permukaan

1. Hasil pengujian alat hummer test Analisis kekuatan struktur bangunan yang 
dilakukan adalah dengan mengetahui mutu beton eksisting dari bangunan dan untuk mutu beton eksisting pada bangunan SDN Cikaret 01 yaitu beton K-225 (setara dengan 18,68 MPa). Mutu beton yang dicari adalah mutu beton elemen struktur bangunan yaitu mutu beton balok, kolom dan pelat. Hal ini dilakukan untuk mengetahui keseragaman mutu beton dipermukaan dan memperkirakan kuat tekan beton struktur bangunan. Untuk mengetahui mutu beton struktur bangunan dengan memperhitungkan kuat tekan beton yang ada. Informasi ini dapat diperoleh dengan cara uji tanpa merusak yaitu dengan hammer test atau palu beton, dimana alat uji ini dapat digunakan untuk menguji dan mengevaluasi kekerasan permukaan beton.

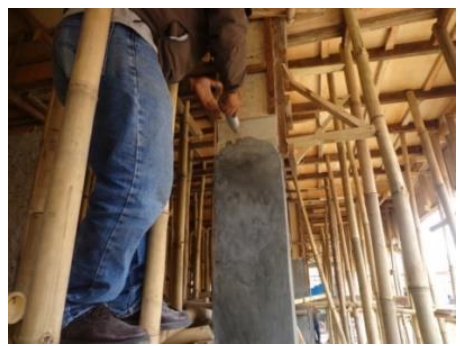

Gambar 3 Proses hummer test
Secara umum faktor-faktor yang dapat mempengaruhi kuat tekan beton seperti:

1) Pengaruh cuaca buruk berupa pengembangan dan penyusutan yang diakibatkan oleh pergantian panas dan dingin.

2) Daya perusak kimiawi, seperti air laut (garam), asam sulfat, alkali, limbah, dan lain-lain.

3) Daya tahan terhadap haus (abrasi) yang disebabkan oleh gesekan orang berjalan kaki, lalu lintas, gerakan ombak, dan lain-lain

4) Bahan-bahan penyusutan beton yaitu air, semen, agregat, admixture, bahan tambahan.

5) Metode pencampuran: penentuan proporsi bahan, pengadukan, pengeceron, pemadatan

6) Perawatan: Pembasahan/perendaman, suhu dan waktu.

7) Keadaan pada saat pengecoran dilaksanakan, yang terutama dipengaruhi oleh lingkungan setempat.

Pengujian beton dilakukan pada struktur kolom beton yang diduga mengalami pelapukan. Sampel benda uji diambil 7 (tujuh) buah kolom, 3 (tiga) buah pelat dan 5 (lima) buah balok yang dipilih secara acak. Bidang uji pada elemen struktur harus memenuhi ketentuan sebagai berikut:

1) Permukaan beton yang akan diuji harus merupakan permukaan yang padat, halus, dan tidak

dilapisi oleh plesteran atau bahan pelapis lainnya.

2) Bidang uji yang dipilih harus kering

\section{Bahan bangunan}

Baja dan halus, bebas dari tonjolan-tonjolan atau lubang- lubang.

3) Lokasi-lokasi bidang uji harus ditentukan sesuai dengan dimensi elemen struktur dan jumlah nilai uji yang diperlukan untuk perhitungan perkiraan kekuatan beton.

\section{Permodelan Struktur \\ Beban \\ Pembebanan}

Jenis pembebanan yang harus diperhitungkan dalam perencanaan gedung ini adalah

beban vertikal. Untuk analisa struktur utama dilakukan kombinasi pembebanan sesuai ketentuan dalam SKSNI 1991. Untuk BebanVertikal dibagi menjadi 3 yaitu :

a. Beban Mati, yaitu berat semua bagian gedung yang bersifat tetap, termasuk segala unsur tambahan, finishing, mesin atau peralatan tetap yang merupakan bagian tak terpisahkan dari gedung itu. Beban mati tersebut sangat tergantung dari dimensi serta berat jenis struktur yang digunakan. Besarnya beban mati suatu gedung/bangunan diperlihatkan dalam Tabel 1.

Tabel 1 Berat Sendiri Bahan Bangunan dan Komponen Gedung

Berat

$7850 \mathrm{~kg} / \mathrm{m}^{3}$ 


\begin{tabular}{lc} 
Beton & $2200 \mathrm{~kg} / \mathrm{m}^{3}$ \\
Beton bertulang & $2400 \mathrm{~kg} / \mathrm{m}^{3}$ \\
Kayu (kelas 1) & $1000 \mathrm{~kg} / \mathrm{m}^{3}$ \\
Pasir (kering udara) & $1600 \mathrm{~kg} / \mathrm{m}^{3}$ \\
\hline & \\
\hline & \\
\hline & $21 \mathrm{~kg} / \mathrm{m}^{2}$ \\
Spesi dari semen, per cm tebal & $250 \mathrm{~kg} / \mathrm{m}^{2}$ \\
Dinding bata merah 1/2 batu & $50 \mathrm{~kg} / \mathrm{m}^{2}$ \\
Penutup atap genting & $24 \mathrm{~kg} / \mathrm{m}^{2}$ \\
\hline Penutup lantai ubin semen per cm tebal
\end{tabular}

b. Beban hidup, yaitu mencakup semua beban yang terjadi akibat pemakaian gedung dan

didalamnya termasuk beban-beban pada lantai yang berasal dari barang-barang, mesin serta peralatan yang tidak merupakan bagian yang tak terpisahkan dan dapat diganti selama masa hidup dari gedung tersebut besarnya beban hidup yang bekerja tergantung dari fungsional gedung atau lantai tersebut (PPI 1983 pasal 3.1 dan 3.2). Besarnya beban hidup ditentukan oleh peruntukan bangunan, dengan harga minimum (Peraturan Pembebanan Indonesia untuk Gedung tahun 1987). beban hidup menurut kegunaan suatu bangunan, ditampilkan dalam Tabel 2.

Tabel 2 Beban Hidup Pada Lantai Gedung

Kegunaan bangunan

Lantai dan tangga rumah tinggal sederhana Berat

Lantai sekolah, ruang kuliah, kantor, toko, toserba, restoran, hotel, asrama, dan rumah sakit Lantai ruang olah raga Lantai pabrik, bengkel, gudang, perpustakaan, ruang arsip, toko buku, ruang mesin, dan lain-lain Lantai gedung parkir bertingkat, untuk lantai bawah $125 \mathrm{~kg} / \mathrm{m}^{2}$ $250 \mathrm{~kg} / \mathrm{m}^{2}$ $400 \mathrm{~kg} / \mathrm{m}^{2}$ (Sumber: Peraturan Pembebanan Indonesia Untuk Gedung, 1983)

c. Beban Gempa, yaitu mencakup semua beban yang bekerja pada struktur yang diakibatkan

oleh gerakan tanah yang merupakan akibat dari gempa bumi (baik gempa tektonik ataupun vulkanik) yang mempengaruhi struktur tersebut. Pembebanan gempa pada bangunan ini menggunakan data peta zona gempa yang ditunjukkan pada Gambar 2.4 dalam hal ini digunakan zone 4 (Peta Zonasi Gempa Indonesia pada SNI-1726$\mathrm{U}=1,4 \mathrm{DL}$ $\mathrm{U}=1,2 \mathrm{DL}+1,6 \mathrm{qLL}$ dengan :

$\mathrm{U}=$ Kuat perlu, $(\mathrm{kN}$ atau $\mathrm{kN} \cdot \mathrm{m})$

$\mathrm{DL}=$ Beban mati, dapat berupa momen maupun gaya dalam akibat beban mati,

$\mathrm{LL}$ = Beban hidup, dapat berupa momen maupun gaya dalam akibat beban hidup,

b. Faktor penentu beban gempa

Beban gempa yang digunakan pada perencanaan.
2012).

\section{Kombiasi pembebanan}

a. Kuat Perlu

Kuat perlu $(\mathrm{U})$ adalah kekuatan minimal struktur yang diperlukan agar dapat menahan kombinasi beban mati, beban hidup dan beban gempa. Kuat perlu harus dihitung dengan ketentuan persamaan: 
Muhamad Lutfi, Subtoni, Kajian Struktur Bangunan Akibat Penurunan Mutu Beton Pada Kolom Terpasang (Studi Kasus: Sdn 01 Cikaret Kabupaten Bogor)

Faktor reduksi kekuatan untuk kolom lebih kecil dibandingkan dengan balok karena kolom umumnya kurang daktil dan lebih terpengaruh terhadap variasi mutu kuat tekan beton. Selain itu, keruntuhan kolom lebih berbahaya dibanding balok. Sedangkan kolom dengan tulangan spiral mempunyai $\varnothing$ yang lebih besar karena lebih daktil dan mempunyai toughness yang lebih besar (toughness adalah kemampuan dalam menyerap enerji). Berdasar Pasal 11.3 SNI 03-2 8472013.

\section{Bentuk pemodelan}

Program Extended three dimensional analysis of building systems (Etabs) merupakan suatu program yang dipergunakan untuk melakukan analisis dan desain pada struktur bangunan. Dengan interface dan tool-tool yang mudah digunakan, Sotwere Etabs akan membantu dalam melakukan analisis dan desain struktur bangunan, yang dahulu dilakukan secara manual dalam waktu yang relatif lama dan keakuratannya tidak terjamin. Pembuatan model struktur pada softwere Etabs 9.7, masing-masing elemen struktur digambarkan dengan sistem grid dengan titik pusat sumbu pada lokasi pusat massa bangunan di lantai dasar.

1. Pondasi

Pada desain permodelan pondasi diasumsikan bahwa pondasi memberikan kekangan translasi dan rotasi yang cukup pada semua arah sumbu bangunan. Pondasi dimodelkan sebagai perletakan jepit pada lantai dasar bangunan yang terletak pada ujung-ujung bawah kolom lantai dasar.

\section{Kolom}

Kolom dimodelkan sebagai elemen frame yang memiliki hubungn (joint) yang kaku sehingga momen maksimum terjadi pada sendi plastis di kedua ujung kolom, momen inersia kolom direduksi menjadi 70\% dari momen inersia awal.

3 Balok

Balok dimodelkan sebagai elemen frame yang memiliki hubungn (joint) yang kaku sehingga momen maksimum terjadi pada sendi plastis di kedua ujung balok untuk memperhitungkan pengaruh retak pada beton ketika terjadinya gempa, momen inersia penampang balok direduksi sehingga momen inersia efektif yang digunakan hanya $35 \%$ dari momen inersia awal (SNI-03-

2847-2002).

4. Pelat lantai

Pada softwere Etabs 9.7, pelat dapat dimodelkan Membrane, dimana pelat lantai dengan jenis ini hanya memiliki kekuatan membran pada kedua arah tegak lurus bidangnya.

\section{METODE PENELITIAN \\ Waktu dan Tempat Penelitian}

Waktu penelitian ini dimulai bulan Mei dan diperkirakan selesai pada bulan Agustus 2016

dan lokasi penelitian yaitu di SDN Cikaret 01 kabupaten Bogor dengan alamat di Jl. Cikaret no 42, Harapan Jaya Kecamatan Cibinong Kabupaten Bogor, yang ditunjukkan pada Gambar 3

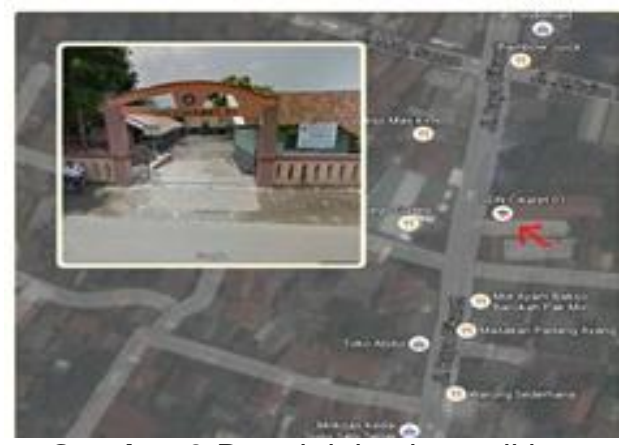

Gambar 3 Denah lokasi penelitian

\section{Bahan dan Alat \\ Bahan}

1) Parameter Struktur

Panjang Bangunan

: 22,50 meter Lebar Bangunan

: 9,00 
meter Jumlah Tingkat meter

2) Denah gedung

Pembangunan gedung sekolah SDN Cikaret 01 kabupaten Bogor terdiri dari 2 lantai dengan 3 bentang balok pada arah X dengan panjang bentang 3 meter dan 4 bentang balok pada arah $\mathrm{Y}$ dengan panjang bentang 4 meter, kemudian 22 kolom tipe 1 dan 11 kolom tipe 2 . Denah kolom lantai 1 ditunjukkan pada Gambar 4, 5 dan 6.

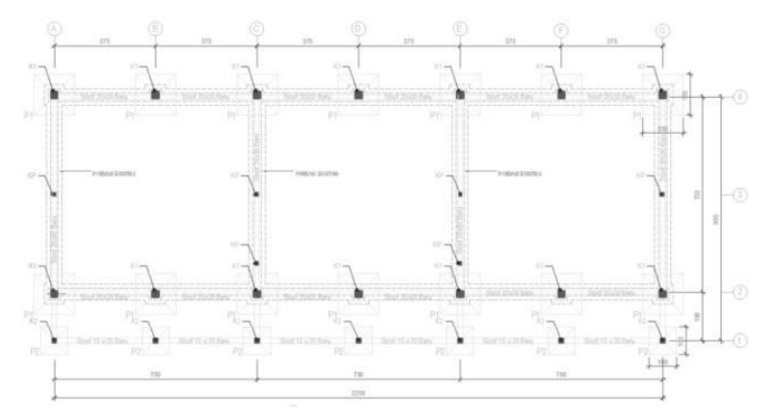

Gambar 4 Denah kolom lantai 1

Detail kolom 1 ditunjukkan pada Gambar 4 dan detail kolom 2 ditunjukkan pada Gambar 5.

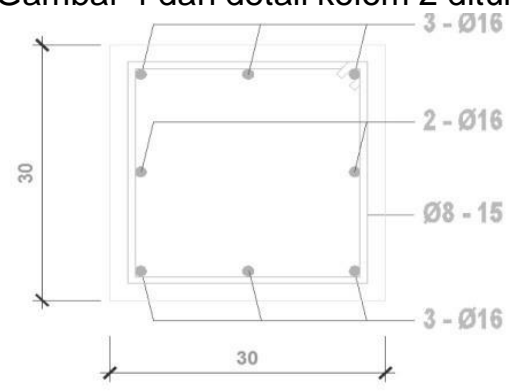

TYPE KOLOM K1 2

Gambar 5 Detail kolom 1
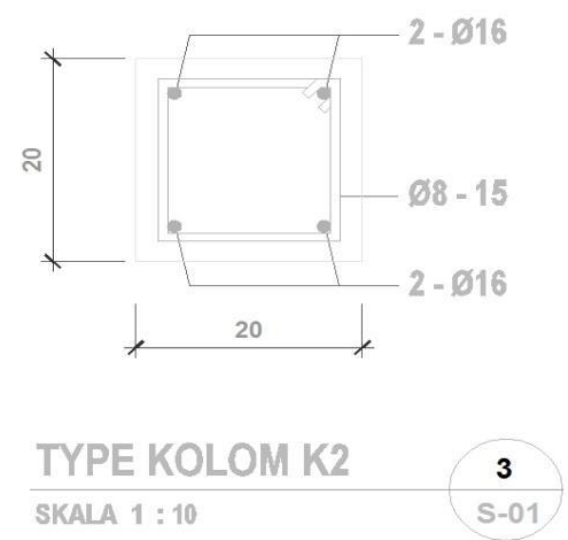

Gambar 6 Detail kolom 2

3). Spesifikasi material

Jenis konstruksi berupa lantai konstruksi beton bertulang, balok anak, atap genteng merah, serta dinding bata merah. Kekuatan karakteristik beton dan baja berdasarkan hasil dari hammer test sebagai berikut:
Kuat tekan beton
$=\mathrm{fc}^{\prime} \quad=6,6 \mathrm{Mpa}$
$=0.0066 \mathrm{kN} / \mathrm{m}^{2}$
Tegangan leleh baja
$=\mathrm{fy} \quad=300 \mathrm{Mpa}$
$=0.30 \mathrm{kN} / \mathrm{m}^{2}$

4). Hasil pengujian hammer test 
Muhamad Lutfi, Subtoni, Kajian Struktur Bangunan Akibat Penurunan Mutu Beton Pada Kolom Terpasang (Studi Kasus: Sdn 01 Cikaret Kabupaten Bogor)

Tabel 3 Pengujian elemen kolom

\begin{tabular}{|c|l|c|}
\hline Jenis Struktur & Lantai 1 & $\mathrm{fc}\left(\mathrm{kg} / \mathrm{cm}^{2}\right)$ \\
\hline \multirow{5}{*}{ Kolom } & Kolom 1 & 103,02 \\
\cline { 2 - 3 } & Kolom 2 & 65,79 \\
\cline { 2 - 3 } & Kolom 3 & 91,80 \\
\cline { 2 - 3 } & Kolom 4 & 84,66 \\
\cline { 2 - 3 } & Kolom 5 & 78,54 \\
\cline { 2 - 3 } & Kolom 6 & 59,16 \\
\cline { 2 - 3 } & Kolom 7 & 73,44 \\
\cline { 2 - 3 } & Rata-rata & $\mathbf{7 9 , 4 9}$ \\
\hline
\end{tabular}

(Sumber: Laboratorim Teknik Sipil FT Unjversitas Pakuan)

Hasil rata-rata kolom : $79,49 \mathrm{~kg} / \mathrm{cm}^{2}$

$$
\begin{aligned}
\mathrm{fc}^{\prime} \quad & =79,49 / 10 \cdot 0,83 \\
& =6,6 \mathrm{Mpa}
\end{aligned}
$$

Tabel 4 Pengujian elemen pelat

\begin{tabular}{|l|l|r|}
\hline Jenis Struktur & Lantai 1 & $\mathrm{fc}\left(\mathrm{kg} / \mathrm{cm}^{\mathrm{L}}\right)$ \\
\hline \multirow{3}{*}{ Pelat } & Pelat 1 & 167,54 \\
\cline { 2 - 3 } & Pelat 2 & 178,94 \\
\cline { 2 - 3 } & Pelat 3 & 151,38 \\
\cline { 2 - 3 } & Rata-rata & $\mathbf{1 6 5 , 9 5}$ \\
\hline
\end{tabular}

(Sumber: Laboratorim Teknik Sipil FT Universitas Pakuan)

Hasil rata-rata pelat $\quad=165,95 \mathrm{~kg} / \mathrm{cm}^{2}$

$=165,95 / 10 \cdot 0,83$

$=12,94 \mathrm{Mpa}$

Tabel 5 Pengujian elemen balok

\begin{tabular}{|c|l|c|}
\hline Jenis Struktur & Lantai 1 & $\mathrm{fc}\left(\mathrm{kg} / \mathrm{cm}^{2}\right)$ \\
\hline \multirow{5}{*}{ Balok } & Balok 1 & 132,40 \\
\cline { 2 - 3 } & Balok 2 & 128,20 \\
\cline { 2 - 3 } & Balok 3 & 134,00 \\
\cline { 2 - 3 } & Balok 4 & 122,40 \\
\cline { 2 - 3 } & Balok 5 & 99,50 \\
\cline { 2 - 3 } & Rata-rata & $\mathbf{1 2 3 , 2 8}$ \\
\hline
\end{tabular}

Hasil rata-rata balok $\quad=123,28 \mathrm{~kg} / \mathrm{cm}^{2}$

$=123,28 / 10 \cdot 0,83$

Universitas Pakuan

$=10,23 \mathrm{Mpa}$

5). Data primer

Data primer adalah data yang diperoleh dari lokasi bangunan maupun hasil survei yang dapat langsung dipergunakan sebagai sumber dalam analisis suatu struktur bangunan. Pengamatan langsung di lapangan mencakup:

$\square \quad$ Kondisi lokasi bangunan gedung tersebut

$\square \quad$ Gambar kerja dari pembangunan gedung

6). Data sekunder

Data sekunder adalah data yang dipakai dalam proses pembuatan dan penyusunan laporan tugas akhir. Data sekunder ini didapatkan bukan melalui pengamatan secara langsung di lapangan. Yang termasuk data sekunder antara lain literaturliteratur penunjang, tabel dan peta (denah) yang

berkaitan erat dengan proses analisis Proyek Pembangunan Gedung SDN

Cikaret 01 Kabupaten

Bogor.

Setelah mengetahui data-data yang diperlukan, langkah selanjutnya adalah menentukan metode pengumpulan data yaitu:

$\square \quad$ Observasi, adalah pengumpulan data melalui peninjauan dan pengamatan langsung di lapangan.

$\square \quad$ Dokumentasi, adalah pengumpulan data dengan mengambil data-data dari uji laboratorium Teknik Sipil Fakultas Teknik Universitas Pakuan, dan foto-foto proses uji hummer test.

Alat

1). Peraturan yang digunakan

Analisis struktur gedung ini menggunakan ketentuan-ketentuan yang berlaku yang terdapat pada buku-buku pedoman antara lain:

1) Tata Cara Perhitungan Struktur Beton Bangunan Gedung SNI 03-2847-2013, diterbitkan oleh

Badan Standarisasi Nasional, Jakarta. 
2) Peraturan Pembebanan Indonesia Untuk Gedung (PPIUG) 1983. Beberapa ketentuan yang diambil dari Peraturan Pembebanan Indonesia Untuk Gedung (PPIUG) 1983 dalam Tugas Akhir ini adalah: Berat sendiri bahan bangunan, beban hidup lantai gedung, beban angina.

2). Alat bantu program komputer

Analisis struktur bangunan dilakukan dengan dua cara yaitu secara manual dan menggunakan program spreedsheet. Adapun maksud memakai program bantu komputer adalah untuk membandingkan antara perhitungan secara manual dan dengan hasil program bantu tersebut. Alat bantu yang dipergunakan adalah:

1) Microsoft Office Excel 2010, digunakan untuk melakukan operasi perhitungan secara manual.

2) Etabs versi 9.7, digunakan sebagai alat bantu permodelan dan perhitungan struktur gedung.

3) Autocad 2007, digunakan untuk menggambar gambar konstruksi yang akan dihitung maupun yang direncanakan.

3). Alat uji lapangan

Evaluasi kuat tekan beton dengan hammer test dilakukan untuk mengetahui keseragaman mutu beton dipermukaan dapat dilakukan dengan cara uji tanpa merusak, sekaligus untuk menguji dan mengevaluasi kekerasan permukaan beton. Metoda pengujian ini dilakukan dengan memberikan beban impact (beban hentakan yang terdapat pada hammer) pada permukaan beton dengan menggunakan suatu massa yang diaktifkan dengan menggunakan energi yang besarnya tertentu.. Bagian-bagian hammer test ditumjukkan pada Gambar 7

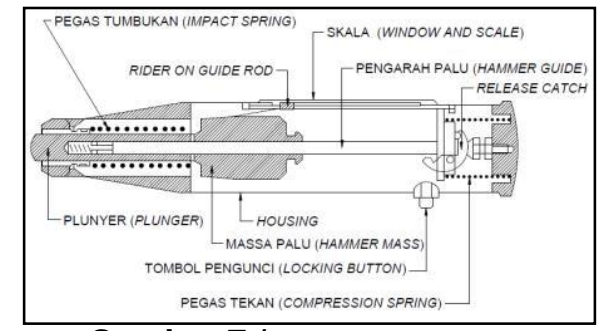

Gambar 7 hammer test

\section{METODE PENELITIAN}

Analisis struktur bangunan dilakukan secara sistematis agar dapat terciptanya pekerjaan yang memenuhi ketentuan minimum serta mendapatkan hasil pekerjaan struktur yang sesuai.

\section{Analisis dan bahasan}

1) Beban Mati (DL)

a. Lantai 1

Plafond

Penggantung

Berat keramik

Berat adukan

Berat dinding

Berat tangga

b. Lantai 2

Plafond

Penggantung

Berat keramik

Berat adukan

Rerat dindino

$$
\begin{aligned}
& =11 \mathrm{~kg} / \mathrm{m}^{2} \\
& =11 \mathrm{~kg} / \mathrm{m}^{2} \\
& =24 \mathrm{Kg} / \mathrm{m}^{2} \\
& =2 \times 21 \mathrm{Kg} / \mathrm{m}^{2} \\
& =4 \mathrm{m \times 2} 250 \mathrm{Kg} / \mathrm{m}^{2} \\
& =1,35 \mathrm{~m}^{3} \times 2400 \mathrm{Kg} / \mathrm{m}^{3} \\
& =11 \mathrm{~kg} / \mathrm{m}^{2} \\
& =11 \mathrm{~kg} / \mathrm{m}^{2} \\
& =24 \mathrm{Kg} / \mathrm{m}^{2} \\
& =2 \times 21 \mathrm{Kg} / \mathrm{m}^{2} \\
& =\Delta \mathrm{m} \times 250 \mathrm{K \sigma} / \mathrm{m}^{2}
\end{aligned}
$$

$$
\begin{array}{lr}
= & 11 \mathrm{Kg} / \mathrm{m}^{2} \\
= & 11 \mathrm{~kg} / \mathrm{m}^{2} \\
= & 24 \mathrm{Kg} / \mathrm{m}^{2} \\
= & 42 \mathrm{Kg} / \mathrm{m}^{2} \\
= & 1000 \mathrm{Kg} / \mathrm{m}^{2} \\
= & 3227,04 \mathrm{~kg} \\
= & 11 \mathrm{Kg} / \mathrm{m}^{2} \\
= & 11 \mathrm{Kg} / \mathrm{m}^{2} \\
= & 24 \mathrm{Kg} / \mathrm{m}^{2} \\
= & 42 \mathrm{Kg} / \mathrm{m}^{2} \\
= & 10 n \cap \mathrm{Ko} / \mathrm{m}^{2} \\
= & 100 \mathrm{~kg} / \mathrm{m}^{2}
\end{array}
$$

Jumlah beban hidup

4) Beban Gempa

Besarnya beban gempa rencana dihitung dari analisis dinamik response spektra. 
Muhamad Lutfi, Subtoni, Kajian Struktur Bangunan Akibat Penurunan Mutu Beton Pada Kolom Terpasang (Studi Kasus: Sdn 01 Cikaret Kabupaten Bogor)

Zona Gempa

Faktor modifikasi respons ( $\mathrm{R})$

Tipe tanah

Periode natural struktur (CT)

Faktor reduksi daktilitas struktur (R)

\section{Pemodelan Struktur Eksisting}

Struktur bangunan SDN Cikaret 01

kecamatan Cibinong Kabupaten Bogor ini terdiri dai

2 lantai struktur dimodelkan sebagai space frame dalam portal 3 dimensi dengan 6 derajat kebebasan (degree of

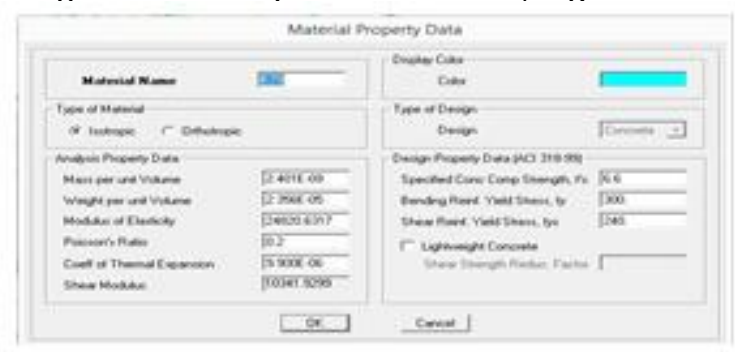

$$
\begin{aligned}
& =\text { Zona ke } 4=0,4 \\
& =3,5 \\
& =\text { Tanah Lunak } \\
& =0,02 \\
& =8,5
\end{aligned}
$$

kemudian didistribusikan ke kolom. Struktur dan elemen struktur dirancang hingga semua penampang mempunyai kuat rencana minimum sama dengan kuat perlu yang dihitung berdasarkan kombinasi beban dan gaya terfaktor sesuai dengan aturan.

\section{Spesifikasi material}

Input yang dilakukan pada softwere Etabs sesuai dengan kekuatan karakteristik beton dan

baja. Input material struktur ditunjukkan pada Gambar 8.

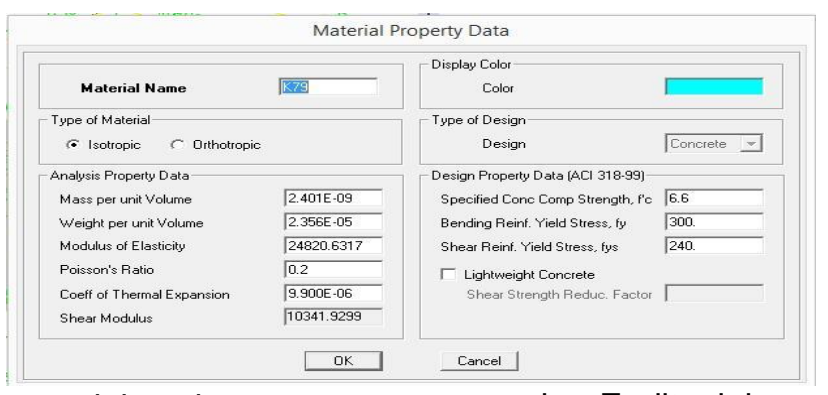

Gambar 8 Input material struktur

sumbu Z ditunjukan dengan notasi Story, sesuai dengan jumlah kolom yang ada pada perencanaan jumlah grid yang dipakai

\section{Grid Struktur}

Pada analisis struktur bangunan SDN Cikaret 01 Kecamatan Cibinong Kabupaten Bogor dengan softwere etabs digunakan dengan grid, dimana grid dengan sumbu $X$ ditunjukan dengan notasi alfabet sedangkan grid sumbu $Y$ ditunjukan dengan notasi angka, kemudian untuk jumlah lantai atau yaitu 10 pada sumbu $X$, 3 pada sumbu $Y$, dan 3 grid pada sumbu $Z$ sesuai dengan jumlah lantai yang ada. Input grid rencana pada softwere Etabs ditunjukkan pada Gambar 9 dan input elevasi rencana ditunjukkan pada Gambar 10.

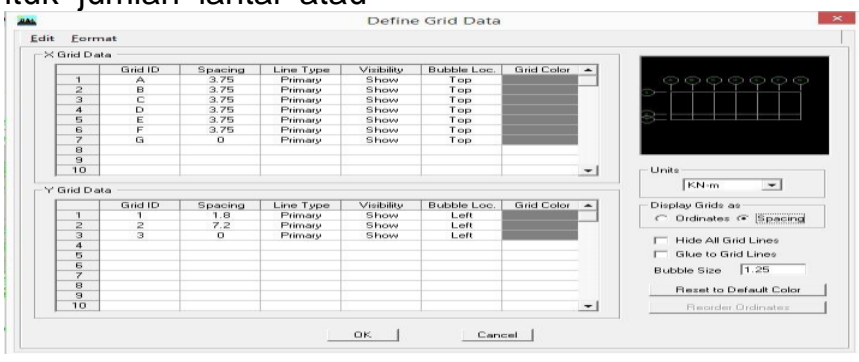

Gambar 9 Grid rencana 


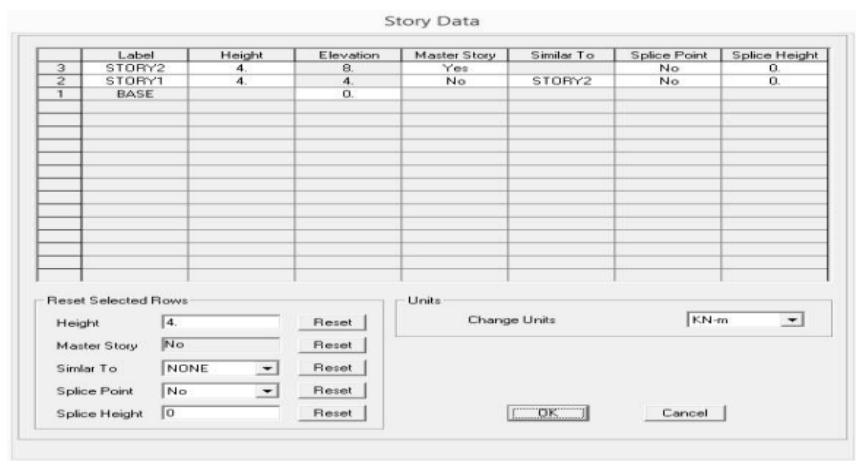

Gambar 10 Elevasi rencana

\section{Input data balok dan kolom}

Pada analisis struktut bangunan SDN Cikaret 01 kecamatan Cibinong Kabupaten Bogor dengan menggunakan sotwere etabs ada beberapa macam dimensi kolom dan balok, penamaan kolom dan balok menggunakan kode sesuai dengan dimensinya, untuk kolom menggunakan kolom $30 \times 30 \mathrm{~cm}$ dan 25×25 cm. Sedangkan untuk balok menggunakan balok dengan dimensi $65 \times 30 \mathrm{~cm}$ dan ukuran $30 \times 20 \mathrm{~cm}$, Input dimensi kolom dan balok ditunjukkan oada Gambar 11 dan contoh input data kolom 25×25 ditunjukkan pada Gambar 12.

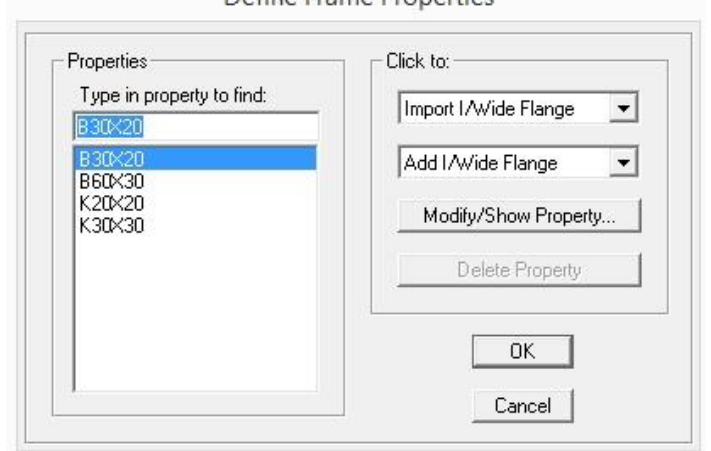

Gambar 11 Input dimensi kolom dan balok

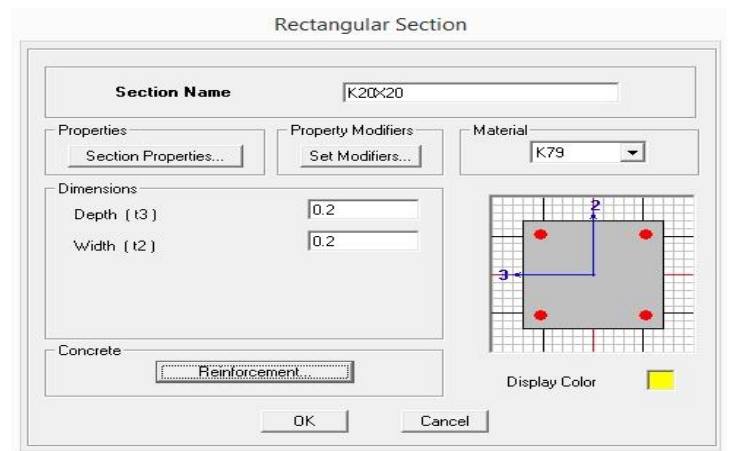

Gambar 12 Contoh input data kolom 20x20 cm

Pembebanan pada software Etabs

Pada permodelan dengan menggunakan softwere etabs beban yang dimasukan yaitu beban hidup, beban mati, beban tambahan yang ditunjukan dalam notasi
SIDL dan beban gempa, untuk beban gempa ditinjau dari dua arah yaitu arah $X$ dan arah $Y$ yang di tunjukan dengan notasi GEMPAX dan GEMPAY. Static load case definition ditunjukkan pada Gambar 13 


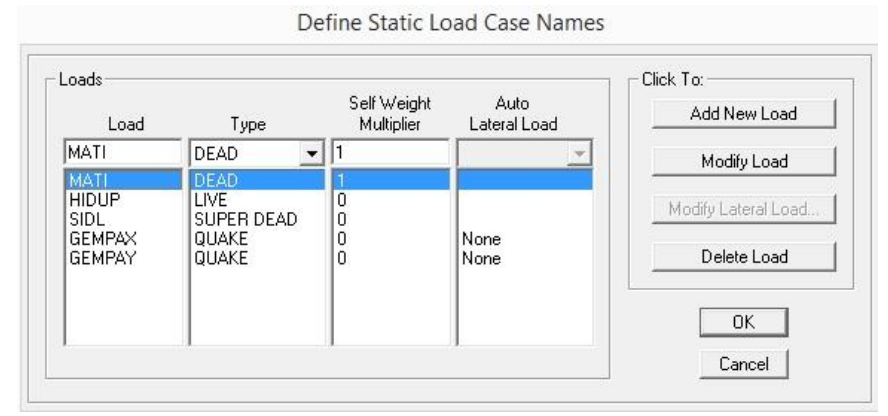

\section{Hasil analisis permodelan}

Gambar 13 Static load case definition

Hasil perhitungan penulangan kolom dan balok dengan kombinasi pembebanan yang telah

ditetapkan dapat dilihat pada gambar dibawah berikut. Tampak bahwa semua elemen kolom atau balok mengalamai over strength (O/S) yang ditandai dengan warna merah pada elemennya. Dengan demikian secara keseluruhan struktur tidak aman terhadap berbagai macam kombinasi beban yang telah ditetapkan, dan kondisi struktur kolom sudah tidak dapat lagi menahan beban struktur ditasnya. Tulangan longitudinal ditunjukkan pada Gambar 14. 


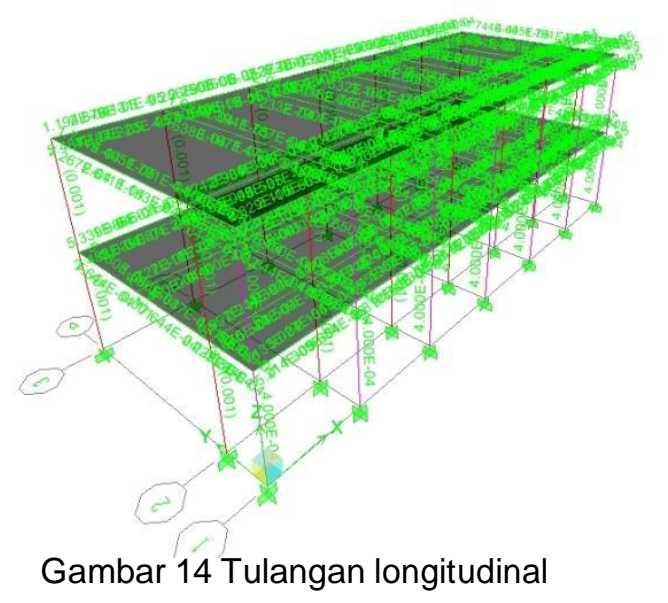

\section{Analisis Struktur Manual Eksisting}

Kolom Desain Forces Kondisi Eksisting pada point 175-177.

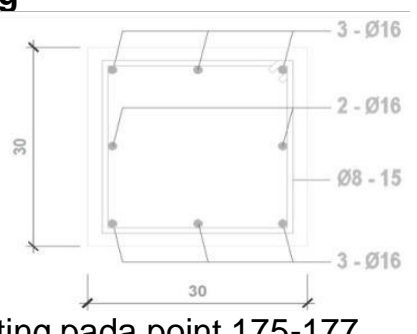

$$
\begin{aligned}
& \mathrm{Pu}(\mathrm{kN})=\begin{array}{lll}
307.72 & 303.40 & 299.07
\end{array} \\
& \begin{array}{lll}
\mathrm{Mu}(\mathrm{kNm})= & 22.51 \quad 5.728 & 33.07
\end{array}
\end{aligned}
$$

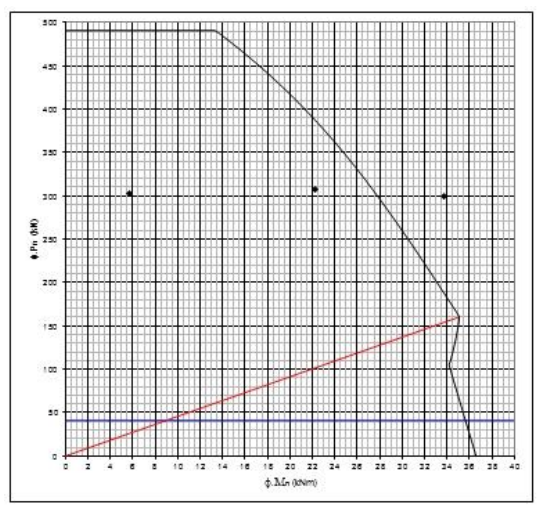

Gambar 15 Diagram interaksi kolom eksisting

Melihat diagram interaksi kolom dapat diketahui hasilnya bahwa struktur kolom tidak dapat menahan beban diatasnya hal itu ditunjukkan dengan adanya $\mathrm{Pu}$ dan $\mathrm{Mu}$ yang berada di luar kuat rencana.

\section{Permodelan Struktur Rencana}

\section{Spesifikasi material}

Sementara itu untuk jenis material yang digunakan yaitu dengan menggunakan material beton dan tulangan baja, berbeda dengan kondisi eksisting pada permodelan ini mutu beton yang digunakan yaitu:

Beton K-225

Tegangan leleh baja

$$
\begin{gathered}
=\mathrm{fc}^{\prime} \quad=18,67 \mathrm{Mpa} \\
=\mathrm{fy}
\end{gathered}
$$

Sementara untuk analisis pembebanan dan dan analisis kondisi tanah masih sama seperti pada permodelan kondisi eksisting. Input material struktur rencana ditunjukkan pada Gambar 16. 
Hasil analisis permodelan

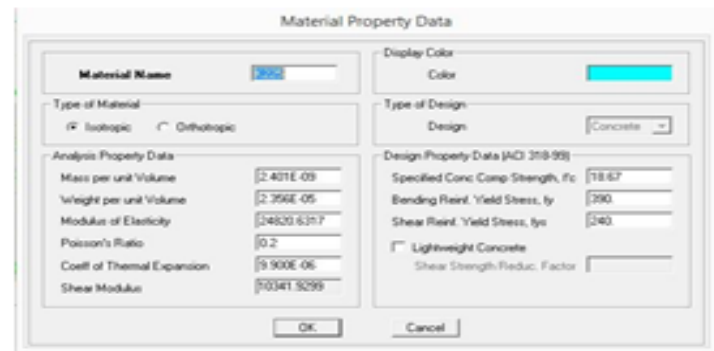

Gambar 16 Input material struktur

Hasil perhitungan penulangan kolom dan balok dengan kombinasi pembebanan yang telah ditetapkan dapat dilihat pada gambar dibawah berikut. Tampak bahwa tidak elemen kolom yang mengalamai over strength (O/S) yang ditandai dengan warna merah pada elemennya. Dengan demikian secara keseluruhan dengan menggunakan mutu beton K-225 struktur aman terhadap berbagai macam kombinasi beban yang telah ditetapkan. Tulangan longitudinal rencana ditunjukkan pada Gambar 17.

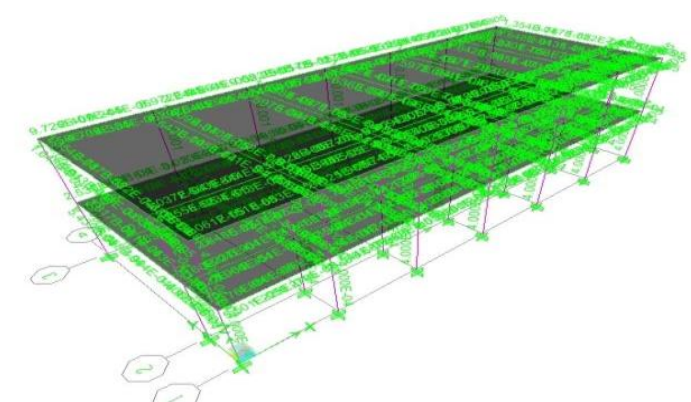

Gambar 17 Tulangan longitudinal

\section{Analisis Struktur Manual Perencanaan}

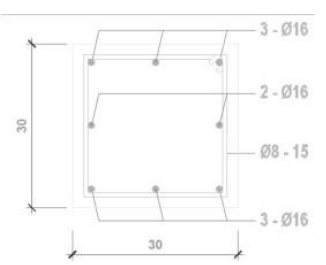

Gambar 18 Detail kolom

Gambar diagram interaksi kolom ditunjukkan pada Gambar 19, dimana untuk nlai kuat rencana dapat dilihat pada lampiran 4 tentang analisis kekuatan kolom beton bertulang dengan diagram interaksi pada kondisi perencanaan nilai Pu dan Mu dapat dilihat dari lampiran 2 Kolom Desain Forces Kondisi Perencanaan pada point 175-177.

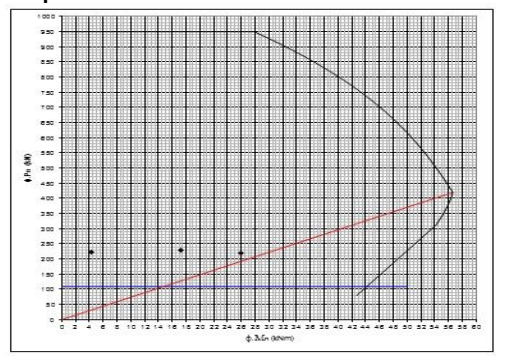

Gambar 19 Diagram interaksi kolom

Dengan melihat hasil dari diagram interaksi kolom didapatkan hasil bahwa struktur kolom dapat menahan beban diatasnya hal itu ditunjukkan dengan semua nilai Mu dan $\mathrm{Pu}$ maksimum yang berada di dalam kuat rencana. 


\section{KESIMPULAN}

Berdasarkan analisis dan bahasan, dengan melakukan pemodelan dengan softwere Etabs

dan analisis struktur manual pada bangunan diperoleh kesimpulan sebagai berikut:

1). Dalam melakukan proses pemodelan dan analisis struktur bangunan pada bangunan SDN 01 Cikaret Kecamatan Cibinong Kabupaten Bogor dapat diketahui bahwa struktur kolom sudah tidak mampu lagi untuk menahan beban struktur diatasnya.

2). Dengan melakukan pengujian mutu beton tanpa merusak atau dengan menggunakan alat hummer test pada kolom, pelat lantai dan balok bangunan SDN 01 Cikaret Kecamatan Cibinong Kabupaten Bogor dapat diketahui bahwa bangunan tersebut mengalami kegagalan struktur pada struktur kolomnya hal itu terbukti dari hasil uji tekan beton menunjukan bahwa mutu beton bangunan pada struktur kolom tidak memenuhi standar minimal mutu beton bagi struktur bangunan tahan gempa.

3). Kegagalan struktutr diperkuat dengan hasil analisis dengan softwere Etabs bahwa struktur kolom mengalami over strength (OS) yang ditunjukkan dengan warna merah dan secara manual pada diagram interaksi nilai Pu dan Mu berada diluar nilai kuat rencana.

4). Dengan melakukan perencanaan ulang dengan permodelan softwere Etabs dan analisis manual tetapi menggunakann material beton dengan mutu K-225 dapat diperoleh bahwa struktur aman, tidak ada struktur yang mengalami over strength (OS) dan dapat menahan beban diatasnya dan pada diagram interaksi nilai Pu dan Mu berada didalam nilai kuat

\section{DAFTAR PUSTAKA}

Asroni, A. 2010. Kolom Pondasi dan Balok T Beton Bertulang. Yogyakarta : Graha Ilmu Asroni, A. 2011. Perencanaan Portal Beton Bertulang Dengan Sistem Daktilitas Penuh Berdasarkan SNI-032847-2002. Program Studi Teknik Sipil, Fakultas Telmik Universitas Muhamadiyah Surakarta

.llham, M. N. 2010. Analisis Kekuatan Kolom

Beton Bertulang Dengan Diagram Interaksi. Yogyakarta.

Nobel, A. 2013. Analisis Struktur Gedung Bertingkat Rendah Dengan Softwere

Etabs V9.5.0. Jurnal Teknik Sipil.

Haykal, M. Analisis Struktur Gedung Bertingkat Rendah Dengan Softwere Etabs V.9.60. Jurnal Teknik Sipil.

Departemen Pekerjaan Umum, 1987. Pedoman Perencaaan Pembebanan Untuk Rumah Dan Gedung tahun 1987. Jakarta. Direktorat Penyelidikan Masalah Bangunan Departemen Pekerjaan Umum, 1983. Peraturan Pembebanan Indonesia untuk Gedung Tahun 1983., Jakarta.

Keputusan Menteri Pekerjaan Umum No: 441/KPTS/1998. Persyaratan Teknis Bangunan Gedung. Jakarta

Material Beton Dan Persyaratannya, Institut Teknologi Sepuluh Nopember SNI 032847-2013, Tata Cara Perhitungan Struktur Beton Untuk Bangunan Gedung

SNI 03-1726-2012, Tata Cara Perencaaan Ketahanan Gempa Untuk Bangunan Gedung UU No. 28 Tahun 2002. 2002. Undang-Undang Tentang Bangunan Gedung. Jakarta. http://puskim.pu.go.id/Aplikasi/desain_s pekt ra_indonesia_2011 